\begin{tabular}{cc|c}
\hline Tar. Bil. Der. & Tarm Bilimleri Dergisi & Journal of Agricultural Sciences \\
& $\begin{array}{c}\text { Dergi web sayfası: } \\
\text { www.agri.ankara.edu.tr/dergi }\end{array}$ & Journal homepage: \\
& www.agri.ankara.edu.tr/journal
\end{tabular}

\title{
Determination of Genotype $x$ Environment Interactions of Some Chickpea (Cicer arietinum L.) Genotypes by Using Different Stability Methods
}

\author{
Omer SOZEN $^{\mathrm{a}}$, Ufuk KARADAVUT ${ }^{\mathrm{b}}$ \\ ${ }^{a}$ Ahi Evran University, Faculty of Agriculture, Department of Field Crops, Kirsehir, TURKEY \\ ${ }^{\boldsymbol{b}}$ Ahi Evran University, Faculty of Agriculture, Biometry and Genetic Unit, Kirsehir, TURKEY
}

\section{ARTICLE INFO}

Research Article DOI: 10.15832/ankutbd.490930

Corresponding Author: Omer SOZEN, E-mail: omer.sozen@ahievran.edu.tr, Tel: +90 (536) 6327555

Received: 26 July 2017, Received in Revised Form: 29 September 2017, Accepted: 10 October 2017

\begin{abstract}
This study was carried out to determine the productive responses of 10 chickpeas (Cicer arietinum L.) genotypes to different places and years. Hasanbey, Aksu, Seckin, Damla 89, Gulumser, Cagatay, Sezenbey, Inci, Gokce and Uzunlu 99 chickpea genotypes were used as plant material. This research was conducted in Yozgat, Kirikkale and Kirsehir Provinces of Turkey in 2014, 2015 and 2016. The experimental design was a randomized block with 4 replicates. Environmental variance, variation coefficient, ecovalance, stability variance, superiority measure, regression coefficient, deviation from regression and coefficient of determination methods were used for stability calculations. Aksu genotype had the highest stability level, whereas Seckin, Damla 89 and Uzunlu 99 chickpea genotypes also successfully grown with respect to stability parameters. Cagatay chickpea genotype showed the highest yield potential, if grown in ideal environmental conditions. To conclude, the ideal yield would be obtained in the event that the requirements of if the genotypes are fulfilled by desired environmental conditions.
\end{abstract}

Keywords: Chickpea; Genotype; Environment; Location; Stability; Yield

(C) Ankara Üniversitesi Ziraat Fakültesi

\section{Introduction}

Chickpea has been an important legume plant for Turkey, especially in Central Anatolia Region including Kirikkale, Yozgat and Kirsehir, consisting of $12.4 \%$ of the cultivation area of Turkey. It has been an important source of dietary protein for human nutrition. As well known, chickpea is self-pollinated, diploid annual grain legume crop (Babagil 2013). Legumes restore soil structure and fertility through biological nitrogen fixation as well as conserving, and improving physical properties of soil via their deep root system and leaving a quite amount of biomass (i.e., nitrogen) to the soil from their leaves due to falling from pulse crops, which will reach to $40 \mathrm{~kg} \mathrm{~N}^{-1}$ (Singh 2016). Local farmers have used local populations and they have been reluctant to switch to other populations for many years. Their local populations can be only sowing in summer season and are highly susceptible to anthracnose (Ascochyta rabiei (pass.) Labr.). Anthracnose emerges especially in heavy spring 
rains and causes huge production losses. Although the studies have shown that sowing chickpeas during fall season yield successful results, it takes time to adapt sowing season. Chickpeas do not resist cold, which is the biggest challenge for fall sowing (Acikgoz et al 2009). Changes in the environment have been important determinants in genotypic performance, identifying the genotypes that can tolerate the changes in the environment is important (Singh \& Bejiga 1990).

The main production goal in legume production has been seed yield and, thus, it is desired to get the sustainable high yield production results with related agronomic properties. The components of genotype $\mathrm{x}$ environment interaction have been recommended for commercial cultivation to get higher yields (Singh et al 2010).

The quantitative properties, such as grain yield, in different plant genotypes grown in a wide environment vary from one environment to another (Altinbas \& Sepetoglu 1994). This phenomenon leads to get different production results from the genotype $\mathrm{x}$ environment interactions in different cultivation conditions (Kilic 2014). The effects of genotype $\mathrm{x}$ environment interaction at significant levels reduce the relationship between genotypic values, preventing the genetic progression expected in breeding, which aim to breed high-quality genotypes (Comstock \& Moll 1963).

Yadav et al (2014) determined that genotype x environment interaction was statistically significant with respect to the studied parameters. High productivity and adaptability to environment depend on the physiological responses of cultivars used in certain environmental conditions (Costa et al 2004). Atta \& Shah (2009) found significant differences in grain yields among genotypes, attributed to these differences to the magnitude of genotypes responses to the environments. According to Farshadfar et al (2011) found out that the environmental effect on yield was $86.44 \%$, whereas the effects of genotype and genotype $\mathrm{x}$ environment interaction were only $2.48 \%$ and $11.08 \%$, respectively. Moreover, breeding genotypes that tolerate environmental conditions has been the cheapest way to control possible negative outcomes and minimizes yield losses (Tsenov et al 2015).

This study was aimed to determine the productive responses of 10 different chickpea genotypes in 3 different environments during 3 years by using different stability parameters.

\section{Material and Methods}

For the current study, 10 registered chickpea genotypes (Cicer arietinum L.) developed by Turkish Research Institutes were used. These were Hasanbey, Seckin, Inci (Eastern Mediterranean Agricultural Research Institute); Cagatay, Sezenbey, Damla 89, Gulumser (Black Sea Agricultural Research Institute); Gokce, Uzunlu 99 (Field Crops Central Research Institute) and Aksu (East Mediterranean Transitional Zone Agricultural Research of Institute) chickpea genotypes. This study was conducted in the locations of Sarikaya/ Yozgat, Keskin/Kirikkale and Center of Kirsehir in Turkey during the period of 2014 and 2016. Altitudes of locations were between 800 and 1300 $\mathrm{m}$. Climate data (Table 1) showed that these three years were similar with respect to the mean monthly temperature and relative humidity. Total amount of precipitation in April and March in all three locations and years was lower than that of rainfall seasons of all three locations and three years. In July, it was excessive.

The trials in all three locations were carried out in a randomized block experimental design with 4 replicates. Seedings were manually performed on rows determined with markers. The trial parcels were made up of 4 rows with $45-\mathrm{cm}$ inter-row spacing and 8 -cm intra-row spacing and total parcel area was $5 \mathrm{~m} \times 1.8 \mathrm{~m}=9 \mathrm{~m}^{-2}$. Harvest area was determined to be $4 \mathrm{~m} \times 0.9 \mathrm{~m}=3.6 \mathrm{~m}^{2}$. The sowing processes were modified according to climate conditions. All planting processes took place in March. Sowings were done in March on 17-19 days, on 20-22 days and on 18-20 days, respective to Yozgat, Kirikkale and Kirsehir locations. Harvesting times were in July on 13-15 days, in March on 10-12 days and in 
Table 1- Climate data for Keskin, Sarikaya and Kirsehir*

\begin{tabular}{|c|c|c|c|c|c|c|c|c|c|c|c|c|c|}
\hline & \multirow{2}{*}{ Months } & \multicolumn{4}{|c|}{$\begin{array}{c}\text { Average temperature } \\
\left({ }^{\circ} \mathrm{C}\right)\end{array}$} & \multicolumn{4}{|c|}{$\begin{array}{l}\text { Total rainfall } \\
(\mathrm{mm})\end{array}$} & \multicolumn{4}{|c|}{$\begin{array}{c}\text { Average relative humidity } \\
(\%)\end{array}$} \\
\hline & & 2014 & 2015 & 2016 & $\begin{array}{l}\text { Long } \\
\text { term }\end{array}$ & 2014 & 2015 & 2016 & $\begin{array}{l}\text { Long } \\
\text { term }\end{array}$ & 2014 & 2015 & 2016 & $\begin{array}{l}\text { Long } \\
\text { term }\end{array}$ \\
\hline \multirow{5}{*}{$\begin{array}{c}\text { Keskin/ } \\
\text { Kirikkale }\end{array}$} & March & 6.4 & 5.4 & 7.3 & 6.9 & 67.0 & 52.0 & 61.6 & 35.9 & 64.2 & 74.2 & 61.9 & 66.3 \\
\hline & April & 11.8 & 8.0 & 13.7 & 12.2 & 7.2 & 18.0 & 22.2 & 44.8 & 49.3 & 58.9 & 45.0 & 50.7 \\
\hline & May & 14.1 & 15.0 & 14.0 & 16.9 & 61.6 & 27.9 & 58.0 & 51.0 & 63.2 & 51.1 & 65.4 & 58.4 \\
\hline & June & 17.6 & 17.6 & 20.3 & 21.2 & 35.8 & 75.4 & 18.8 & 36.8 & 55.2 & 68.0 & 50.5 & 63.5 \\
\hline & July & 23.5 & 22.1 & 23.0 & 24.6 & 1.4 & 0.0 & 1.2 & 10.9 & 38.1 & 45.2 & 41.7 & 42.4 \\
\hline \multirow{5}{*}{$\begin{array}{l}\text { Sarikaya/ } \\
\text { Yozgat }\end{array}$} & March & 7.0 & 5.7 & 6.7 & 2.8 & 86.4 & 74.9 & 38.4 & 64.7 & 62.0 & 73.2 & 60.1 & 63.5 \\
\hline & April & 12.4 & 7.7 & 13.4 & 8.3 & 14.2 & 29.6 & 20.2 & 59.4 & 52.3 & 64.0 & 44.8 & 55.6 \\
\hline & May & 14.9 & 14.9 & 13.9 & 13.1 & 50.2 & 54.4 & 57.9 & 66.8 & 61.5 & 60.3 & 64.6 & 60.7 \\
\hline & June & 17.9 & 16.9 & 19.1 & 16.7 & 46.4 & 43.5 & 8.9 & 43.2 & 58.3 & 73.0 & 58.6 & 64.9 \\
\hline & July & 22.9 & 20.4 & 21.2 & 19.5 & 0.5 & 2.1 & 0.0 & 12.0 & 45.0 & 55.8 & 50.8 & 52.3 \\
\hline \multirow{5}{*}{$\begin{array}{l}\text { Center/ } \\
\text { Kirsehir }\end{array}$} & March & 7.4 & 7.0 & 7.1 & 5.2 & 56.0 & 87.8 & 44.8 & 39.0 & 64.4 & 76.2 & 60.7 & 67.5 \\
\hline & April & 13.2 & 8.8 & 13.8 & 10.7 & 23.2 & 26.4 & 24.0 & 42.2 & 54.8 & 66.2 & 47.4 & 59.7 \\
\hline & May & 16.3 & 16.0 & 14.9 & 15.5 & 46.6 & 27.4 & 98.2 & 44.8 & 61.3 & 58.1 & 63.7 & 56.2 \\
\hline & June & 19.9 & 18.4 & 21.0 & 19.7 & 36.0 & 141.1 & 18.5 & 33.9 & 54.1 & 66.9 & 53.0 & 50.9 \\
\hline & July & 25.5 & 23.0 & 24.2 & 23.1 & 13.4 & 20.3 & 5.8 & 6.6 & 39.2 & 47.0 & 42.5 & 38.4 \\
\hline
\end{tabular}

*, Turkish State Meteorological Service

March on 7-9 days, respective to Yozgat, Kirikkale and Kirsehir locations.

In sowing time at all locations, $25 \mathrm{~kg} \mathrm{ha}^{-1}$ pure nitrogen and $50 \mathrm{~kg} \mathrm{ha}^{-1}$ pure phosphorus fertilizers were used. During the trial, among the stability parameters, environmental variance (Lin et al 1996), variation coefficient (Francis \& Kannenberg 1978), ecovalance (Wricke 1962), stability variance (Shukla 1972), superiority measure (Lin \& Binns 1988), regression coefficient (Eberhart \& Russel 1966), deviation from regression (Becker \& Leon 1988) and coefficient of determination (Pinthus 1973) methods were used in stability calculations. From these methods, coefficients and their deviations from regressions were considered to be stable. In addition, environmental and genotype indices were calculated. The results were evaluated by applying variance analysis in accordance with the different years and repeated randomized block experimental design used in the SPSS 17 package program.

\section{Results and Discussion}

The variance analyses of the experiment are shown in Table 2, revealing that the differences among the years, locations and genotypes and their interactions were statistically significant $(\mathrm{P}<0.01)$.

Table 2- Analysis of variance results of chickpea yield for different location and years

\begin{tabular}{lcr}
\hline Source & $\begin{array}{c}\text { Degree of } \\
\text { freedom }\end{array}$ & Mean square \\
\hline Year & 2 & $37,915.84 * *$ \\
Location & 2 & $356,415.58^{* *}$ \\
Year x Location & 4 & $319,348.96^{* *}$ \\
Genotype & 9 & $31,677.61^{* *}$ \\
Year x Genotype & 18 & $10,112.34^{* *}$ \\
Location x Genotype & 18 & $9,980.14^{* *}$ \\
Year x Location x Genotype & 36 & $8,017.56^{* *}$ \\
Error & 244 & $1,106.11^{* *}$ \\
Total & 360 & \\
Coefficient of variation & $10.32 \%$ & \\
\hline
\end{tabular}


According to Table 2, Year $\mathrm{x}$ Location $\mathrm{x}$ Genotype interaction was statistically important. Also, it is observed that the observed differences between years seriously affected the properties of the genotypes by combining with the locational characteristics. The efficacies of the Year $x$ Genotype and Location x Genotype interactions had quite importance, showing that these effects were very strong. Both the location and the year had significant impacts on the formation of genotypes, resulting different productive outputs between the present cultivated genotypes. The significant location $\mathrm{x}$ genotype interactions with respect to yield were shown on the efficacy of environment on the genotypes by affecting the productive yields of the experimental plants.

This result supports the report of Farshadfar et al (2011) in which they determined that the contribution of environment on yield change was $86.44 \%$. This result is also in line with that of Altınbas \& Sepetoglu (1994) in which they stated that the responses of the characters vary depending on the environment. The differences among the cultivars were of great importance because of the fact that all investigated properties of the cultivars showed similar behaviors (Sabanduzen \& Akcura 2017). The significance of Genotype $x$ Environment interaction was also determined in the studies of Arshad et al (2003), Bakhsh et al (2006), Abbas et al (2008), Ali \& Sarwar (2008) and Karasu et al (2009), on chickpeas, white beans, green peas and soy beans, respectively.

Table 3 shows the yields of the genotypes with respect to the locations in which they were grown for 3 years. Table 3 reveals that, in the Sarikaya/Yozgat location, the highest yield was obtained in Cagatay genotype $\left(1,832.2 \mathrm{~kg} \mathrm{ha}^{-1}\right)$, whereas the lowest yield was obtained in Gokce genotype $\left(1,544.6 \mathrm{~kg} \mathrm{ha}^{-1}\right)$. In Keskin/Kirikkale location, Cagatay genotype (1,904.3 $\mathrm{kg} \mathrm{ha}^{-1}$ ) was the most prominent genotype and showed the highest yield, while the lowest-yielding genotype was Gokce genotype $\left(1,696.5 \mathrm{~kg} \mathrm{ha}^{-1}\right)$.

In Kirsehir location, Cagatay genotype did not reach the performance as reached in the other two locations. The highest yield was obtained in Aksu genotype $\left(1,678.2 \mathrm{~kg} \mathrm{ha}^{-1}\right)$. Gokce genotype was more successful in this location and was among the highest-ranking genotypes. The lowest yield was observed in Hasanbey genotype $\left(1,406.8 \mathrm{~kg} \mathrm{ha}^{-1}\right)$.

In general, it can be argued that the genotypes demonstrated significant differences among each other and these differences varied depending on the sowed locations. The comparison between the average yields of the locations showed that Sarikaya/ Yozgat and Keskin/Kirikkale locations were in the same group, while Center/Kirsehir location was different from the other two locations and had the

Table 3- Yield situations of genotypes according to locations $\left(\mathrm{kg} \mathrm{ha}^{-1}\right)$

\begin{tabular}{lccccc}
\hline Genotypes & Sarikaya/Yozgat & Keskin/Kirikkale & Center/Kirsehir & Mean & Genotype index \\
\hline Cagatay & $1,832.2$ & $1,904.3$ & $1,532.4$ & $1,756.3$ & 82.9 \\
Aksu & $1,755.3$ & $1,761.4$ & $1,678.2$ & $1,731.6$ & 58.4 \\
Seckin & $1,675.9$ & $1,774.3$ & $1,621.4$ & $1,690.5$ & 17.1 \\
Uzunlu 99 & $1,719.3$ & $1,709.6$ & $1,613.2$ & $1,680.7$ & 7.3 \\
Damla 89 & $1,700.6$ & $1,713.8$ & $1,621.7$ & $1,678.7$ & 5.3 \\
Gulumser & $1,778.6$ & $1,708.2$ & $1,496.3$ & $1,661.0$ & -12.4 \\
Hasanbey & $1,825.9$ & $1,705.3$ & $1,406.8$ & $1,646.0$ & 27.4 \\
Sezenbey & $1,764.1$ & $1,697.0$ & $1,467.1$ & $1,642.7$ & -30.7 \\
Inci & $1,623.7$ & $1,714.9$ & $1,564.2$ & $1,634.3$ & -39.1 \\
Gokce & $1,544.6$ & $1,696.5$ & $1,594.8$ & $1,612.0$ & -61.4 \\
\hline Mean & $1,722.0 \mathrm{~A}$ & $1,738.5 \mathrm{~A}$ & $1559.6 \mathrm{~B}$ & $1,673.4$ & \\
\hline Environment index & 48.6 & 65.1 & -113.8 \\
\hline
\end{tabular}


lowest yield. This difference is attributable to the ecological factors.

Plant physiology is highly susceptible as a result of their sensitive mechanism of action and it gains further importance when their yield capacities are in question. The degree of their reactions is not only dependent on their genotypic structure but also is affected by factors interacting with the environment and environment (Sehirali \& Ozgen 1988; Kabak \& Akcura 2017). Therefore, different genotypes in different environments may show different performances (Acikgoz \& Acikgoz 1994; Altinbas et al 1999). It was reported that the yield and certain properties of plants showed significant variations depending upon the environment, most likely, affecting the yield at significant levels (Silim \& Saxena 1993; Yucel \& Mart 2014).

Chickpea can show different phenological reactions or responses to climate conditions. This consequently will affect plant growth and productivity in different way. Additionally, location effect contributed this efficacy. Climate changes will affect early growth and flowering by changing dry matter content, the numbers of fertile and dropped flowers (Garcia Del Moral et al 2003). Rainy conditions in different locations affected the environmental responses of plants. The difference in adaptation abilities of genotypes plus rainy conditions both increased the intense of their environmental responses. However, plants would have eliminated the negative consequents of climate changes when they grew up sufficiently (Saidi et al 2008). In our present study, it can be said that the genotypes affected from environmental factors in lesser extent, showed the better growth performance than the others.

Figure 1 shows the mean yield values of genotypes for experimental years and locations, revealing that Hasanbey, Gulumser and Sezenbey chickpea genotypes showed poor performances in all environments; Cagatay genotype was different from the other genotypes and yielded high in good environments, although its yield decreased in environments where its physiological requirements were not met. Aksu, Seckin, Damla 99 and Uzunlu 99 genotypes maintained their yields under all

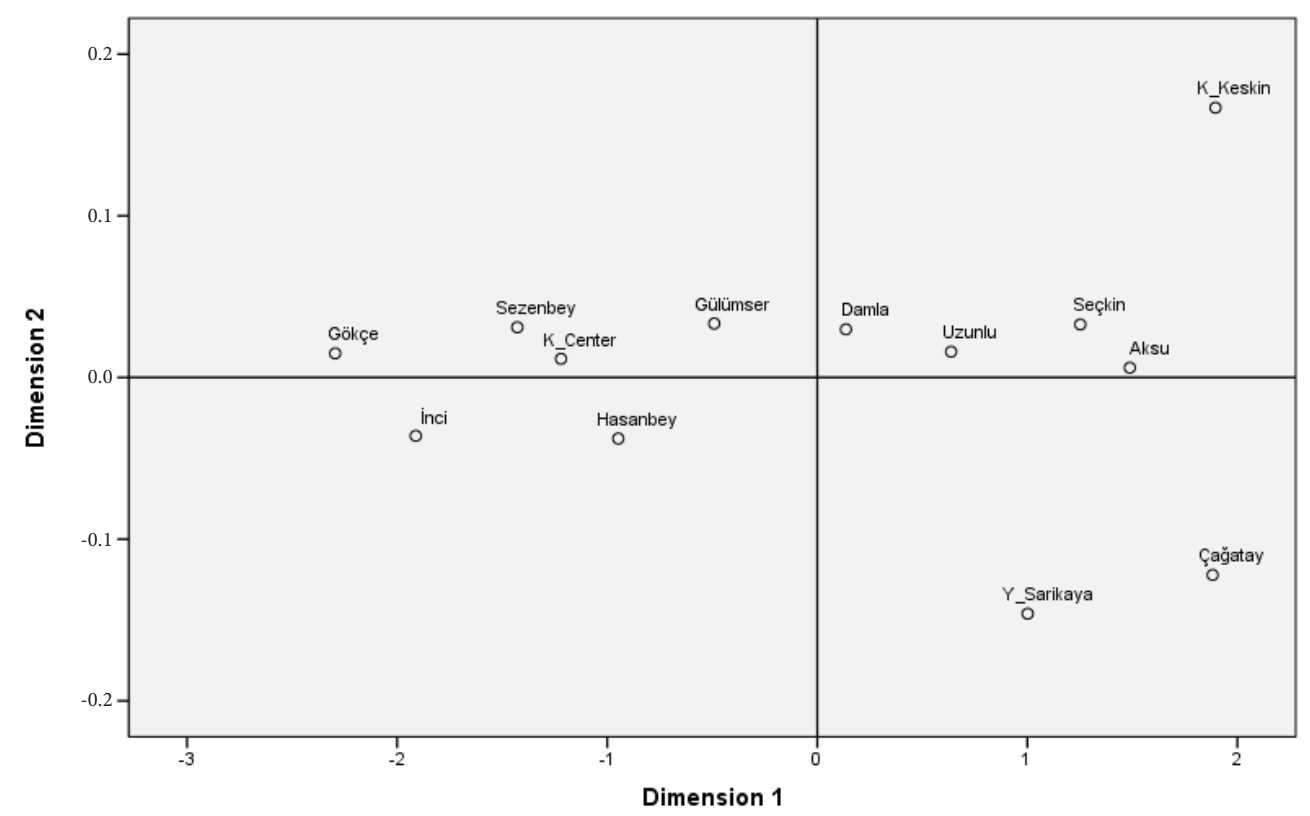

Figure 1- Multi dimentional scaling of location, year and genotypes performance 
conditions while Inci and Gokce genotypes maintained their yields at acceptable levels, even under unfavorable conditions.

Table 4 shows the results of the different stability parameters applied to the chickpea genotypes used in the present study. Table 4 reveals that, in the view of the investigated parameters, Aksu, Seckin, Uzunlu 99 and Damla 89 genotypes were more stable than the other genotypes in terms of all years and locations, whereas Hasanbey, Gulumser and Sezenbey genotypes were not stable in any environment or location and showed significant changes, depending on their sowed environments and years.

Regression coefficient and deviation from regression indicated the stability of a cultivar: the closer the regression coefficient was to 1 and the smaller the deviation from regression, the more stable the cultivar. Furthermore, coefficient of determination $\left(\mathrm{R}^{2}\right)$ shows how much of the variation in a dependent variable can be explained with the regression equation and therefore, cultivars with higher $\mathrm{R}^{2}$ values can be accepted as more stable cultivars (Unay et al 1990; Aleksoska et al 2015).

Eberhart \& Russel (1966) evaluated the genotypes as stable if their regression coefficients $\left(b_{i}\right)$ are ' 1.0 ' and their deviations from regression can be statistically accepted as " $\left(S_{d i}^{2}=0\right)$ " and stated that genotypes with higher performances in all environments were desired. Therefore, it can be concluded that the regression coefficient used by Eberhart \& Russel (1966) was the same as that of Finlay \& Wilkinson (1963).

Table 4- Stability parameters of genotypes for different location and years

\begin{tabular}{lccccccccc}
\hline Genotypes & $\vec{X}$ & $S_{x i}^{2}$ & $b_{i}$ & $S_{d i}^{2}$ & $R^{2}$ & $W_{i}^{2}$ & $\sigma_{i}^{2}$ & $C V_{i}$ & $P_{i}$ \\
\hline Hasanbey & 164.5 & 4.26 & 1.65 & 3.58 & 0.86 & 6.38 & 0.61 & 32.1 & 2.58 \\
Aksu & 173.1 & 1.68 & 1.08 & 1.14 & 0.95 & 2.18 & 1.10 & 24.3 & 1.14 \\
Seckin & 169.0 & 1.88 & 0.96 & 1.06 & 0.94 & 2.07 & 1.06 & 23.8 & 1.16 \\
Damla 89 & 167.8 & 2.61 & 0.95 & 0.94 & 0.94 & 2.36 & 1.21 & 24.4 & 1.18 \\
Gulumser & 166.0 & 8.36 & 0.68 & 4.26 & 0.76 & 7.11 & 3.16 & 32.6 & 3.54 \\
Cagatay & 177.0 & 3.22 & 0.92 & 1.20 & 0.89 & 2.84 & 1.28 & 25.1 & 2.20 \\
Sezenbey & 164.2 & 7.69 & 0.69 & 3.91 & 0.79 & 6.74 & 3.37 & 35.6 & 3.94 \\
Inci & 163.4 & 3.56 & 1.10 & 1.36 & 0.88 & 2.66 & 2.47 & 27.1 & 2.21 \\
Gokce & 161.1 & 3.54 & 1.09 & 1.42 & 0.87 & 2.71 & 2.64 & 27.6 & 1.96 \\
Uzunlu 99 & 168.0 & 2.05 & 0.94 & 1.14 & 0.94 & 2.11 & 1.18 & 23.8 & 1.29 \\
\hline
\end{tabular}

\section{Conclusions}

The results of the present study showed that, according to the parametric stability tests, the Aksu cultivar had the highest stability level. Seckin, Damla 89 and Uzunlu 99 chickpea genotypes grew up successfully. Cagatay chickpea genotype has the highest yield potential, if it grew up under proper breeding conditions; however, such conditions cannot be continuously provided and, therefore, successful results cannot be expected from this genotype. Inci and Gokce chickpea genotypes should be considered as the potential successful genotypes.
The tendency of the higher yields were observed in the Keskin/Kirikkale location without showing any statistical difference between locations.

\section{References}

Abbas G, Atta B M, Shah T M, Sadiq M S \& Haq M A (2008). Stability analysis for seed yield in mungbean (Vigna radiata L.). Wilczek Journal of Agriculture Research 46: 223-228

Acikgoz N \& Acikgoz N (1994). Determination of the effects of different sowing time and varieties on the 
formation of yield by path analysis. Field Crops Congress 1: 121-125

Acikgoz E, Ustun A, Gul I, Anlarsal E, Tekeli A S, Nizam I, Avcioglu R, Geren H, Cakmakci S, Aydinoglu B, Yucel C, Avci M, Acar Z, Ayan I, Uzun A, Bilgili U, Sincik M \& Yavuz M (2009). Genotype x Environment interaction and stability analysis for dry matter and seed yield in field pea (Pisum sativum L.). Spanish Journal of Agriculture Research 7: 96-106

Aleksoska A, Miceska G, Gveroska B, Dimitrieski M \& Aleksoski J (2015). Stability of the yield in commercial tobacco varieties in Republic of Macedonia. Turkish Journal of Agriculture Natural 2: 1391-1395

Ali Y \& Sarwar G (2008). Genotype x Environment interaction of cowpea genotypes. International Journal of Environment Research 2(2): 125-132

Altinbas M \& Sepetoglu H (1994). A study on the determination of stability parameters for seed yield and some agronomic properties in lentil (Lens culinaris Med.). The first Field Crops Congress 4: 116-120

Altinbas M, Sepetoglu H \& Karasu A (1999). A Research on fertility effects of chickpea under different environmental conditions. The First Field Crops Congress, 25-29 April 1994, Izmir 3: 348-353

Arshad M, Bakhsh A, Haqqani A M \& Bashir M (2003). Genotype $\mathrm{x}$ Environment interaction for grain yield in chickpea (Cicer arietinum L.). Pakistan Journal of Botany 35: 181-186

Atta B M \& Shah T M (2009). Stability analysis of elite chickpea genotypes tested under diverse. Australian Journal of Crop Science 3: 249-256

Babagil G E (2013). Assessment of effectiveness degrees of the factors affecting the yield of some chickpea (Cicer arietinum L.) genotypes by path analysis. Indian Journal of Agriculture Science 83: 1205

Bakhsh A, Arshad M \& Haqqani A M (2006). Effect of Genotype x Environment interaction on relationship between grain yield and its components in chickpea (Cicer arietinum L.). Pakistan Journal of Botany 38(3): 683-690

Becker H C \& Leon J (1988). Stability analysis in plant breeding. Plant Breeding 101: 1-23

Comstock R E \& Moll R H (1963). Genotype x Environment Interactions. Statistical Genetics and Plant Breeding NAS-NRC Publ No: 982, Washington DC., pp. 164-196
Costa J M, Bollero V S \& Pandey P L (2004). Stability for grain yield of barley genotypes under rainfed conditions. Advance in Plant Science 12: 27-30

Eberhart S A \& Russel W A (1966). Stabilty parameters for comparing varieties. Crop Science 6: 36-40

Farshadfar E, Farshadfar M \& Kiani M (2011). Involvement of chromosome 5R carrying the genes controlling yield and yield stability in rye (Secale Cereale cv. Imperial). European Journal of Science Research 59(3): 352-360

Finlay K M \& Wilkinson G N (1963). The analysis of adaptation a plant-breeding programme. Australian Journal of Agriculture Research 14: 742-754

Francis T R \& Kannenberg L W (1978). "Yield stability studies in short season maize 1, A Descriptive method for grouping genotypes", Canadian Plant Science 58: 1029-1034

Garcia Del Moral L F, Rharrabti Y, Villegas D \& Royo C (2003). Evaluation of grain yield and its components in drum wheat under Mediterranean conditions: an ontogenic approach. Agrononomy Journal 95: 266274

Kabak D \& Akcura M (2017). Evaluation of the interrelationship among grain yield traits of rye landraces population collected from Bingol province using biplot analysis. Turkish Journal of Agricultural and Natural Sciences 4(2): 227-235

Karasu A, Oz M, Goksoy A T \& Turan Z M (2009). Genotype by environment interactions stability and heritability of seed yield and certain agronomical traits in soybean (Glycine $\max$ (L.) Merr.). African Journal of Biotechnology 8(4): 580-590

Kilic H (2014). Assessment of advanced durum wheat lines for yield and some quality traits at different environments. Turkish Journal of Agricultural and Natural Sciences 1(2): 194-201

Lin C C \& Binns M R (1988). A superiority measure of cultivar performance for cultivar x location data. Canadian Journal of Plant Science 68: 193-198

Lin C C, Binns M R \& Lefkovitch L P (1996). Stability Analysis: Where Do We Stand? Crop Science 26: 894-900

Pinthus M J (1973). Estimate of genetic value: Proposed methods. Euphytica 22: 121-123

Sabanduzen B \& Akcura M (2017). Evaluation of grain yield and yield components of oat genotypes in 
Canakkale conditions. Turkish Journal of Agricultural and Natural Sciences 4(2): 101-108

Saidi A, Ookawa T, Motobayashi T \& Hirasawa T (2008). Effects of soil moisture conditions before heading on growth of wheat plants under drought conditions in the ripening stage: insufficient soil moisture conditions before heading render wheat plants more resistant to drought to ripening. Plant Production Science 11: 403-411

Sehirali S \& Ozgen M (1988). Plant Breeding. University of Ankara Faculty of Agricultural Publications 1059, Textbook: 310, Ankara

Shukla G K (1972). "Some statistical aspects of partitioning genotype $\mathrm{x}$ environmental components of variability". Heredity 29: 237-245

Silim S N \& Saxena M C (1993). Yield and water use efficiency of faba bean sown at two row spacings and seed densities. Expriment Agriculture 29: 173-181

Singh R (2016). Productivity enhancement of chickpea (Cicer arietinum L.) through improved production technologies on farmer's field. Indian Journal of Agricultural Sciences 86(10): 1357-1360

Singh K B \& Bejiga G (1990). Analysis of stability for some characters in kabuli chickpea. Euphytica 49: 223-227
Singh T, Paswan S \& Tyag J P (2010). Effect of environmental stresses on certain quality traits in chickpea (Cicer arietinum L.). Indian Journal of Agricultural Sciences 80(12): 1089-1091

Tsenov N, Gubatov T, Atanasova D, Nankova M \& Ivanova A (2015). Genotype x Environment effects on the productivity traits of common wheat (Triticum aestivum L.) II. Analysis of genotype reaction. Turkish Journal of Agricultural and Natural Sciences 1: 1198-1208

Unay AI, Turgut H, Surek H \& Korkut K Z (1990). Stability analysis on some properties in rice. University of Ankara Faculty of Agricultural Publications 3(1-2): 117-124

Wricke G (1962). On a method of understanding the biolojical diversity in field research. Zoology Pflanzenzucht 47: 46-92

Yadav A, Yadav I S \& Yadav C K (2014). Stability analysis of yield and related traits in chickpea (Cicer arietinum L.). Legume Research 37(6): 641-645

Yucel D \& Mart D (2014). Drought tolerance in chickpea (Cicer arietinum L.) genotypes. Turkish Journal of Agricultural and Natural Sciences 1: 1299-1303 